\title{
Marketing Communication Strategy To Improve Tourism Potential
}

\author{
M. Ali Syamsuddin Amin', Peri Priansah ${ }^{2}$ \\ ${ }^{1,2}$ Communication Studies Department, Majalengka, Indonesia \\ m.ali.syamsudin@gmail.com
}

\begin{abstract}
One of the main cultural attractions and the main attraction of tourism in the Kuningan regency is Curug Putri Palutungan. The tourism potential of the Kuningan regency was also supported by good access and transportation facilities. To reach the tourist attraction area that once was separated by many rivers, several bridges were built to facilitate tourists the tourist attraction. The tourist potential of the Curug Putri Palutungan is a mixture of the natural charm of mountainous forests and clear waterfalls, backed by a fresh mountain air that challenges you to explore the nature of the mystery of the forest. In this article, the authors use a qualitative method when conducting descriptive studies on the object of writing, because this method is an appropriate method to search for social fields and in particular communication. Qualitative writing methods that will be used to better understand the phenomena related to psychological aspects, behavior, attitudes, responses, opinions, feelings, desires and desires of a person or group. The marketing communication strategy of the Office of Youth, Sports, and Tourism to increase the tourism potential of the regency of Curug Putri Palutungan is one of them through advertising, that is, the installation of banners/billboards, print media advertising, online media advertising, Kuningan FM radio ads.
\end{abstract}

Keywords: marketing communication; tourism potential; Kuningan.

\section{Introduction}

Tourism is an industrial sector which is currently got a lot of attention from many countries in the world. The tourism sector is believed to have the ability to increase economic growth (Maciej Debski 2013). Moreover, the tourism sector is positively encouraged to be able to replace the oil and gas sector which has been the main capital in the country's foreign exchange earnings (Siswanto 2007). The advantage of the tourism sector lies in its ability to increase foreign exchange and to drive various other business sectors such as the home industry. Thus, developed countries and developing countries continue to develop and improve the quality of their country's tourism.

Kuningan Regency has a great tourism potential sector which can be improved. Kuningan Regency is located at the foot of Mount Ciremai, the coordinates of $108^{\circ} 23-108^{\circ}$ $47 \mathrm{~N}, 6^{\circ} 47-7^{\circ} 12 \mathrm{~W}$. Meanwhile, the capital city is located at the coordinates of $6^{\circ} 45-7^{\circ}$ $50 \mathrm{~N}, 105^{\circ} 20-108^{\circ} 40 \mathrm{~W}$. The eastern part of the regency is lowland while the western part is mountains, with the peak of Mount Cermai $(3.076 \mathrm{~m})$ on the border with Majalengka Regency. Mount Ceremai is the highest mountain in West Java (Youth, Sport, and Tourism Office, Kuningan, 2016).

One of the superior cultural attractions as well as the main tourism in Kuningan Regency is Curug Putri Palutungan. Curug Putri Palutungan is located in Cigugur District. Because it's located right at the foot of Mount Ciremai, someone needs to pass curved and uphill road, like climbing a mountain, to reach this place. Palutungan means monkey nest in Sundanese. In addition to being used as a campsite, there are several waterfalls in Palutungan. The closest waterfall is called Curug Putri and the farthest is called Curug 
Mangkok. Kuningan Regency tourism potential has also been supported by good access and transportation facilities. The way to get to that location was once separated by many rivers. However, several bridges have been built to facilitate tourists to tourist attractions. Also, the causeway to get to Kuningan Regency has been built well by the government (Disporapar Kab. Kuningan, 2016). The tourism potential in Curug Putri Palutungan is a blend of the natural charm of the mountainous forests and clear waterfalls, supported by cool air challenging the visitors to tour the nature of the forest. The available facilities are rafting, camping area, shelter, guard post, working hut, signboard, clean water installation, trash can, bench, toilet, and praying room. You can also relax and enjoy the available snacks there.

Kuningan Regency Government was aware of the importance of increasing the potential of cultural tourism by establishing a long-term vision as a center for tourism which is developed and prosperous. The vision was realized by appointing the Office of Youth, Sports, and Tourism as a mean in managing, guiding, and promoting tourism objects in Kuningan District. However, the efforts have not reached maximum results. Various potentials are hidden and not yet widely known. Over the past six years, the number of tourists has not increased significantly. From 2010 to 2016, the number of visitors was only in the range of 30,000 to 35,000. The data show that there is no increased demand for the tourism sector in Kuningan Regency (Disporapar Kab. Kuningan, 2016).

The promotion has a significant role in tourism development because it is related to efforts in communicating tourism potential to the target audience. Marketing communication becomes a strategic alternative solution in promoting a business to consumers in winning a very tight competition (Gorlevskaya 2016). Thus, innovative marketing communication, especially through social media, has a positive impact on tourist destinations (Lim, Chung, and Weaver 2012). Even though the tourist attraction is has been well available with the help of adequate access and attractive pricing, it will be in vain without communicating with consumers (Kotler 2012). Moreover, tourism is a service business where it has its uniqueness compared to the product business because the object being marketed as something intangible (Kotler 2012). Therefore, a good communication strategy in the marketing process of tourism attraction is needed.

As a body that has been appointed by the Kuningan regency government to organize Kuningan tourism marketing promotion, the Office of Youth, Sports, and Tourism is demanded to be active in creating effective promotions to achieve the set goals. Thus, the researchers were interested in conducting a study to investigate the promotion strategies that have been carried out by the Regional Government through the Office of Youth, Sports, and Tourism in Kuningan Regency in developing Kuningan tourism as natural potential based tourism.

Promotion strategy is a concept that is close to communication science. In the promotion, there are various forms of communication learned in communication science such as advertising, publicity, communication from mouth to mouth, personal sales, and direct marketing.

\section{Literature Review}

In company operations, marketing communication has a very important role. In an organization or company, marketing communication has the role of providing information, persuading, and reminding consumers directly or indirectly about the products and brands sold (Philip Kotler 2009). Marketing communication performs many functions to consumers 
or target markets, especially to inform and show about how and why the product is used, who the target market is, as well as where and when the product can be obtained. The marketing communication environment by the development of communication process technology has also changed, as has been the case with the recent rise in internal development. The presence of the Internet has an impact on marketing tourism (Gonca Guzel Sahin 2018; Tembi Maloney Tichaawa, Oswald Mhlanga 2017). Accordingly, it also affects the consumers in obtaining information about a product. The more specific study concluded that social media determine and influence consumer decisions in buying a product or service (Icoz, Kutuk, and Icoz 2018).

Marketing communication can shape brand equity and improve promotional performance (Bogan 2014). The development of marketing communication that changes very rapidly through advertising is not the only or the most important thing in establishing brand equity and driving sales, but can also be a mean which increases equity and drive sales through a mix of marketing communication. Moreover, expanding this communication can also make the product or tourism object reach a wider market. Marketing communication mix is done to encourage the effectiveness and efficiency of marketing communication which consists of eight main communication models, including advertising, sales promotion, events and experience, public relations, direct marketing, interactive marketing, word of mouth marketing, and sales personnel (Philip Kotler 2009).

Communication is the process of delivering messages by someone to other people to tell, change attitudes, opinions or behavior either directly orally or indirectly through the media. In this communication requires a reciprocal relationship between the delivery of messages and recipients namely communicators and communicants (Hasbullah, et al: 2018)

In this study, researchers employed the Marketing Mix Theory (marketing mix) in which this theory explained the promotional mix, a mean that marketers can use to establish the characteristics of services offered to customers. The promotional mix concept according to (Philip Kotler 2009) consists of advertising, sales promotion, personal selling, and public relations. Stanton defined promotional mix as a combination of the best strategies of advertising variables, personal sales, and other promotional tools. All of which are planned to achieve the objectives of the sales program (Stanton 2008). Promotion is one of the determining factors for the success of a marketing program that can provide motivation (Font and Mccabe 2017) and information (Gil-saura 2011). However qualified a product is, if consumers have never heard of it and are not sure that the product will be of use to them, they will never buy it.

\section{Research Methodology}

A qualitative method was employed in this study by using a descriptive study on the object of the study. This method was considered to be an appropriate method for investigating social fields especially its communication aspect. A qualitative method was used to get a better understanding of the phenomena from the aspects of psychological, behavior, attitudes, responses, opinions, feelings, desires, and wishes of a person or group. The researchers had examined Instagram as a marketing communication instrument to attract consumers' interest. However, the researchers did not become part of the instrument because the researchers were excluded from the marketing activity. This study focused on the meaning of the respondents. Thus, selected respondents were interviewed to explore certain descriptive studies. In-depth interviews and observation might have been done to investigate 
events (the process of events), certain behaviors or attitudes by approaching the respondents concerned as an object of this qualitative study. Meanwhile, the descriptive method was employed to describe and analyze the data by collecting data based on real conditions. This qualitative study with a descriptive approach aimed to get a general understanding of social reality from the respondents' perspective. Their understanding was not determined in advance but was obtained after analyzing the social reality which became the focus of this study. Then, a conclusion was drawn in the form of a general understanding of those facts.

\section{Discussion}

Promotion strategies carried out by the Kuningan Youth, Sports, and Tourism Office were so varied (mix promotion). Promotion in marketing communication involved the use of communication instruments. The mix promotion model showed a different promotional mix model which were carefully blended. Thus, mix promotion was used by Kuningan Youth, Sports, and Tourism office as their marketing communication.

\section{a. Marketing communication strategy through advertising}

\section{- Banners / Billboards}

Ahead of events in Kuningan, billboards and large banners in strategic places were installed. From the results of observations, the researchers found large billboards about tourism marketing, especially ahead of major events on the highway in the Kuningan.

- Print Media Advertising

The tourism promotion activities conducted Youth, Sports, and Tourism Office of Kuningan Regency, one of which is the Curug Putri Palutungan, were by placing advertisements in local and national print media, such as the Pikiran Rakyat newspaper which published the news "Curug Putri Become the Mainstay of Kuningan Tourism". In the photo, several young women took pictures with Curug Putri Palutungan as the background.

- Online Media Advertising

Lately the trend of "back to nature" tourism or nature recreation has been increasing. Thus, Kuningan Youth, Sports, and Tourism Office were in collaboration with several local or national online media to promote its tourism to report interesting tourism programs especially natural tourism. One of the collaboration can be seen on the YouTube channel namely "Welcome to Our Channel Jelajah Kuningan (Kuningan Exploration)".

- Ads on Kuningan FM Radio

Tourism potential of Curug Putri Palutungan was promoted through Kuningan FM radio broadcast which office was located at J1. Aruji Kartawinata No. 3 Kuningan, Postal Code 45511, Phone No. (0232) 8894507. The broadcast was conducted every day at 5 and 12 local time. The radio announcer in charge of informing Curug Putri Palutungan tourism potential was Ucup Supratman. The broadcast was in the form of a talk show with Youth, Sports, and Tourism Office in the context of tourism socialization in Kuningan. In this socialization, a representative from the Youth, Sports, and Tourism Office of Kuningan gave directions to the people of Majalengka, Cirebon, Kuningan, and its surrounding areas who would travel to Kuningan Regency.

\section{b. Marketing communication strategy through direct marketing - Blocking TV}


Lately, the trend of "back to nature" tourism or natural recreation has increased. It can be seen from the shows on several television stations that broadcast very interesting tourist programs, especially natural tourism. This is an opportunity for Curug Putri Palutungan attraction to develop natural attractions as one of its attractions.

Welcome to Our Channel jelajah Kuningan, West Java is a channel that introduces cultural diversity, tourist attraction, special culinary, and all about Kuningan Regency, West Java. It had explored a tourist attraction located at the foot of Mount Ciremai, namely Curug Putri Palutungan tourism object located in Palutungan village, Cigugur, Kuningan Regency, West Java.

- Internet Marketing

Internet marketing through Kuningan Youth, Sports, and Tourism Office website in promoting all tourism potential had been done and can be accessed in https://www.kuningankab.go.id/pemerintahan/skpd/dinas-pemuda-olah-raga-dan-pariwisatakabupaten-kuningan. In addition, Internet marketing had also been done through Instagram of Kuningan Youth, Sports, and Tourism Office to promote tourism potential in Kuningan Regency, one of which is Curug Putri Palutungan. Internet marketing is a form of marketing strategy considered quite significant in implementing marketing strategiesfor tourist areas in Kuningan. This finding was by some studies (Bogan 2014; Yoon and Petrick 2016) which concluded that Internet marketing is very effective in promoting a product.

\section{c. Marketing communication strategy through personal selling}

- Travel Dialog Program

Kuningan Youth, Sports, and Tourism Office partnership development programs were an increase in cooperation between tourism organizations, tourism business partnership forums, Kuningan Regency tourism business services certification, tourism business service partnership development, tourism business service competition, creating business service profiles of Kuningan Regency tourism, workshops on empowering tourism activists group, and tourism workforce certification.

- Workshop

The Kuningan Regency Youth, Sports, and Tourism Office held a workshop for tourism operators. The workshop was not held in a luxury hotel or hall, but in a tourist attraction instead. Recently, an agency led by Jaka Chaerul held a workshop for tourism actors. Surprisingly, the workshop was not held in star hotels or luxurious halls, but in tourist attractions. In the records of the managers of attractions, the number of tourists coming to several attractions continued to increase. Moreover, the construction of the hotel also grew along with the number of restaurants around the areas near to the attraction.

- Tour guide training

The Youth, Sports, and Tourism Office conducted tour guide training. This training was expected to serve foreign tourists. Thus, they can enjoy the beauty of Kuningan much longer. Kuningan Youth, Sports, and Tourism office trained 50 young men and women to prepare Kuningan as a tourist destination.

\section{d. Marketing communication strategy through Sales Promotion}

- Discount Price

The manager facilitated visitors who wanted to camp in the tourist spot various camping equipment such as tents, mattresses, mats, sleeping beds, electricity usage facilities, 
firewood, snacks, et cetera. Meanwhile, according to Agus, the entrance fee which needed to be paid by the visitors was Rp 22,000 for each person excluding the vehicle units brought. Another attraction possessed by Palutungan natural tourism was the discounted price during national holidays such as entrance fee for 13,000/person (insurance included), flying fox ride ticket for Rp 20,000/person, outbound/fun games price for Rp 10,000/person.

- Launching Ayo Wisata

Recently, Ayo Wisata was launched. Secretary of Youth, Sports, and Tourism Office, Dr. H. Toto Toharuddin, M.Pd, stated that the Minister of Youth and Sports was planned to be present at the multi-event tournament event held by his institution. The tournament which was opened by the Minister of Youth and Sports consisted of a bamboo festival, underground parade, traditional sports, youth volleyball, and the launched of Ayo Wisata.

\section{e. Marketing communication strategies through public relations}

- Information Center

The Office of Youth, Sports, and Tourism provided a tourist information center in Tourism Village of Cibuntu Pasawahan Subdistrict Kuningan as well as at the office of Youth, Sports, and Tourism Office. The vision of the Kinungan Regency as stated in the Vision of the Kuningan Tourism and Culture Office was "to realize independent, religious, and prosperous Kuningan through advanced, excellence, and sustainable culture and naturebased tourism in 2018".

- Cooperation with Perhutani

Youth, Sports, and Tourism Office evaluated the marketing program being carried out and decided to cooperate with Perhutani in terms of the development and management of attractions. This was to create a good internal relationship.

- Tourism Activists Group

Tourism was developed by empowering the community around attractions including forming Tourism Activists Group. Forming Tourism Activist Group made the citizens became more responsive to the development of tourism. Tourism Activists Group in the Palutungan region played a role in the development of tourism, especially in tourism awareness. The results of this study indicate that public relations were very important in the promotion activities carried out. The results of the analysis have proven that public relations activities had been realized in 3 categories which were information centers, cooperation, and forming tourism drivers. The findings of this study are consistent with the study conducted by (Arionesei, Gabriela \& Ivan 2012) which showed that tourist destinations are driven by the relational public managers.

\section{Conclusion}

Marketing communication strategy of the Office of Youth, Sports, and Tourism in increasing the tourism potential of Curug Putri Palutungan in Kuningan through advertising was in the form of the installation of banners/billboards, print media advertisements, online media advertisements, and broadcast on Kuningan FM radio. Marketing communication strategy of the Office of Youth, Sports, and Tourism in increasing the tourism potential of the Curug Putri Palutungan in Kuningan Regency through direct marketing was in the form of Blocking TV and Internet marketing such as using websites and Instagram. Marketing communication strategy of the Office of Youth, Sports, and Tourism in increasing the 
tourism potential of the Curug Putri Palutungan in Kuningan Regency through personal selling was in the form of travel dialogs, workshops, and training of tour guides. Marketing communication strategy of the Office of Youth, Sports, and Tourism in increasing the tourism potential of the Curug Putri Palutungan in Kuningan Regency through sales promotion was in the form of price discounts and launching Ayo Wisata. Marketing communication strategy of the Office of Youth, Sports, and Tourism in increasing the tourism potential of the Curug Putri Palutungan in Kuningan Regency through public relations was in the form of the information center, cooperation with Perhutani, and tourism activist community.

\section{References}

Arionesei, G. and Ivan, P. (2012). "Marketing of Tourism Destinations From The Public Relations' Perspective". Journal of Tourism - Studies and Research in Tourism 1(90): $75-82$.

Bogan, E. (2014). "Communication and Promoting Policy in Tourism Marketing." 1(1): 1-6.

Debski, M. (2013). "Marketing Communication as a Tool of Building Tourism Destination Competitiveness-Selected Issues." Management 17(1): 259-72.

Font, X. and Mccabe, S. (2017). "Sustainability and Marketing in Tourism : Its Contexts, Paradoxes, Approaches, Challenges, and Potential." Journal of Sustainable Tourism 9582. https://doi.org/10.1080/09669582.2017.1301721.

Gil-saura, I. (2011). "Integrated Marketing Communications and Information and Communication Technology in the Hotel Sector: An Analysis of Their Use and Development in Dalmatian Fi Rst-Class and Luxury Hotels." 9: 401-14.

Gorlevskaya, L. (2016). "Building Effective Marketing Communications in Tourism.” Studia commercialia Bratislavensia 9(35): 252-65.

Hasbullah, Hatta, M., and Arifin, Z. (2018). Communication Pattern of Wilayatul Hisbah, Lhokseumawe City in Implementing Amar Makruf Nahi Mungkar. Budapest Internation Research and Critics Institure Journal. Vol. 1, No. 4, 194-205.

Icoz, O., Kutuk, A., and Icoz, O. (2018). "Social Media and Consumer Buying Decisions in Tourism : The Case of Turkey." 16: 1051-66.

Kotler, P., and Armstrong, G. (2012). Principles Of Marketing, 14th Edition. New Jersey: Prentice-Hall Published.

Kotler, P., and Keller, K., L. (2009). Marketing Management. 13th Edition. New Jersey: Pearson Prentice Hall.

Lim, Y., Chung, Y., and Weaver, P., A. (2012). "The Impact of Social Media on Destination Branding : Videos versus Destination Marketer Generated Videos.” Journal of Vacation Marketing 18(3): 197-206.

Sahin, G., G., and Sengün, G. (2018). "The Effects of Social Media on Tourism Marketing: A Study among University Students." 4(5): 772-86.

Siswanto. (2007). Objek Wisata Dan Jenisnya Dalam Pandangan Pengembangan Parawisata. Jakarta: Kanisius.

Stanton, W., J. (2008). Fundamental of Marketing. New York: Mc. Graw Hill Inc.

Tichaawa, T., M., Mhlanga, O., and Sicwebu, S. (2017). "The Impact of Information Communication Technologies (ICTs) on Tourism Businesses in East London, South Africa." Economica 13(3). 